\begin{tabular}{|c|l|}
\hline Title & $\begin{array}{l}\text { Comparative study on enzymatic characteristics of try psins from the py loric ceca of yell ow tail (Seriola quinqueradiata) } \\
\text { and brown hakeling (Phy sicul us japonicus) }\end{array}$ \\
\hline Author(s) & Kishimura, Hideki; Tokuda, Y usuke; Klomklao, Sappasith; Benjakul, Soottawat; A ndo, Seiichi \\
\hline Citation & $\begin{array}{l}\text { Journal of Food Biochemistry, 30(5), 521-534 } \\
\text { https://doi.org/10.1111/.1745-4514.2006.00079.x }\end{array}$ \\
\hline Issue Date & $2006-10$ \\
\hline Doc URL & http://hdl.handle.net/2115/30126 \\
\hline Rights & The definitive version is available at www.blackwell-synergy.com \\
\hline Type & article (author version) \\
\hline File Information & JFB30-5.pdf \\
\hline
\end{tabular}

Instructions for use 
Running title: Trypsin from yellow tail and brown hakeling

\title{
COMPARATIVE STUDY ON ENZYMATIC CHARACTERISTICS OF TRYPSINS \\ FROM THE PYLORIC CECA OF YELLOW TAIL (SERIOLA QUINQUERADIATA) \\ AND BROWN HAKELING (PHYSICULUS JAPONICUS)
}

\author{
HIDEKI KISHIMURA ${ }^{1}$, SAPPASITH KLOMKLAO ${ }^{2}$, \\ SOOTTAWAT BENJAKUL ${ }^{2}$ AND SEIICHI ANDO ${ }^{3}$
}

${ }^{1}$ Laboratory of Marine Products and Food Science, Research Faculty of Fisheries Sciences, Hokkaido University, Hakodate, Hokkaido 041-8611, Japan

${ }^{2}$ Department of Food Technology, Faculty of Agro-Industry, Prince of Songkla University, Hat Yai, Songkhla 90112, Thailand

${ }^{3}$ Faculty of Fisheries, Kagoshima University, Shimoarata, Kagoshima 890-0056, Japan

\footnotetext{
${ }^{1}$ Author for corresponding. TEL : +81-138-405519; FAX : +81-138-405519;

EMAIL : kishi@fish.hokudai.ac.jp (H. Kishimura).
} 


\section{ABSTRACT}

Trypsins from the pyloric ceca of two fish species, yellow tail (Seriola quinqueradiata) and brown hakeling (Physiculus japonicus) were purified by a series of chromatographic separations. Purity increased 63- and 106-fold with approximately 55 and $10 \%$ yield for yellow tail trypsin and brown hakeling trypsin, respectively. Final enzyme preparations were homogeneous in sodium dodecyl sulfate-polyacrylamide gel electrophoresis (SDS-PAGE) and the molecular weights of both enzymes were estimated to be $24 \mathrm{kDa}$ by SDS-PAGE. Yellow tail and brown hakeling trypsins had maximal activity at $\mathrm{pH}$ 8.0 for hydrolysis of TAME and was unstable at acidic $p H$. The optimum temperatures for yellow tail and brown hakeling trypsins were $60 \mathrm{C}$ and $50 \mathrm{C}$, respectively. Yellow tail trypsin was stable up to $50 \mathrm{C}$, whereas brown hakeling was stable up to $40 \mathrm{C}$. Both trypsins were stabilized by calcium ions. The activities of both trypsins were strongly inhibited by soybean trypsin inhibitor and TLCK and partially inhibited by EDTA. The N-terminal amino acid sequences of yellow tail trypsin and brown hakeling trypsin were determined as IVGGYECKPYSQPHQVSLNS and IVGGYECTPHSQAHQVSLNS, respectively. 


\section{INTRODUCTION}

Trypsin (EC3.4.21.4) specifically cleaves the peptide bonds on the carboxyl side of arginine and lysine residues and has been identified in a wide variety of organisms (Rypniewski et al. 1994). Bovine trypsin was among the first proteolytic enzymes isolated and analyzed. In the pancreas, trypsin not only functions as a digestive enzyme, but also is responsible for activating all the pancreatic enzymes, including itself, by cleaving a short activation peptide from the amino-terminus of inactive zymogens. Mammalian pancreatic trypsin and its proenzyme have been extensively characterized (Walsch 1970; Kossiakoff et al. 1977).

On the other hand, the marine environment presents an excellent opportunity for supplying commercial enzymes. Marine animals possess the same functional classes of enzymes as other living organisms, which enable them carry out virtually the same metabolic activities. These enzymes are present in the tissues of animals and may be recovered in active and stable forms for commercial use. In several of the major fish-producing countries, the by-products of seafood harvesting comprise about $50 \%$ of the entire harvest. These materials are largely underutilized and discarded as waste. However, this abundant material also includes the enzyme-rich digestive organs, and the enzymes may be recovered and used for a range of commercial applications. Furthermore, fishes are poikilothermic, so their survival in cold waters required adaptation of their enzyme activities to low temperatures of their habitats. Enzymes from cold adapted fish species thus often have higher enzymatic activities at low temperatures than their counterparts from warm-blooded animals (Simpson and Haard 1984; Asgeirsson et al. 1989; Kristjansson 1991). High activity of fish enzymes at low temperatures may be interesting for several industrial applications of enzymes, such as in certain food processing operations, i.e. production of cheese, cold fining of beverages and a 
digestive aid in fish feed (Haard 1992) that require low processing temperatures. Moreover, relatively lower thermal stability, often observed with fish enzymes, may also be beneficial in such applications as the enzymes can be inactivated more readily, with less heat treatment, when desired in a given process (Simpson and Haard 1987).

Trypsins have been isolated and characterized from several species of fish including capelin (Hjelmeland and Raa 1982), catfish (Yoshinaka et al. 1983), Greenland cod (Simpson and Haard 1984), anchovy (Martinez et al. 1988), Atlantic cod (Asgeirsson et al. 1989), rainbow trout (Kristjansson 1991), Monterey sardine (Castillo-Yanez et al. 2005), and Japanese anchovy (Kishimura et al. 2005a). In previous studies, we isolated trypsins from the viscera of true sardine (Sardinops melanostictus) and from the pyloric ceca of arabesque greenling (Pleuroprammus azonus) (Kishimura et al. 2005b). The characteristics of these trypsins suggest that the viscera of true sardine and the pyloric ceca of arabesque greenling would be a potential source of trypsin for food processing operations. Such information is not available for trypsin from the pyloric ceca of yellow tail and brown hakeling. In this study, we purified trypsins from the pyloric ceca of yellow tail (Seriola quinqueradiata) and brown hakeling (Physiculus japonicus) and compared their characteristics to those of porcine pancreatic trypsin.

\section{MATERIALS AND METHODS}

The yellow tail (S. quinqueradiata) and brown hakeling (P. japonicus) were caught off Hakodate, Hokkaido Prefecture, Japan. Sephacryl S-200 and Sephadex G-50 were purchased from Pharmacia Biotech (Uppsala, Sweden). Diethylaminoethyl (DEAE)-cellulose was purchased from Whatman (Maidston, England). $\quad N a$ 
-p-Tosyl-L-arginine methyl ester hydrochloride (TAME) and ethylenediaminetetraacetic acid (EDTA) were obtained from Wako Pure Chemicals (Osaka, Japan). 1-(L-trans-epoxysuccinyl-leucylamino)-4-guanidinobutane $\quad$ (E-64), $\quad$ N-ethylmaleimide, iodoacetic acid, soybean trypsin inhibitor, $N$-p-tosyl-L-lysine chloromethyl ketone (TLCK), $N$-tosyl-L-phenyl-alanine chloromethyl ketone (TPCK), and pepstatin A were purchased from Sigma Chemical Co. (St. Louis, Mo, USA).

Defatted powders of the pyloric ceca of yellow tail and brown hakeling were prepared by the same method of Kishimura and Hayashi (2002). Trypsin was extracted by stirring from the defatted powder in 50 volumes of $10 \mathrm{mM}$ Tris-HCl buffer (pH 8.0) containing $1 \mathrm{mM} \mathrm{CaCl} 2$ at $5 \mathrm{C}$ for $3 \mathrm{~h}$. The extract was centrifuged (H-200, Kokusan, Tokyo, Japan) at $10,000 \times \mathrm{g}$ for $10 \mathrm{~min}$, and then the supernatant was concentrated by lyophilization and used as crude trypsin.

Crude trypsin from yellow tail was applied to a column of Sephacryl S-200 (3.9×64 $\mathrm{cm}$ ) pre-equilibrated with $10 \mathrm{mM}$ Tris- $\mathrm{HCl}$ buffer ( $\mathrm{pH}$ 8.0) containing $1 \mathrm{mM} \mathrm{CaCl}_{2}$ at $5 \mathrm{C}$ and the proteins were eluted with the same buffer at a flow rate of $27 \mathrm{ml} / \mathrm{h}$. Each $4.0 \mathrm{ml}$ fraction was collected. The main trypsin fractions (about $60 \mathrm{ml}$ ) were pooled and concentrated by lyophilization to $4.0 \mathrm{ml}$. The concentrated fraction was then applied to a Sephadex G-50 column $(3.9 \times 64 \mathrm{~cm})$ pre-equilibrated with $10 \mathrm{mM}$ Tris-HCl buffer $(\mathrm{pH}$ 8.0) containing $1 \mathrm{mM}$ $\mathrm{CaCl}_{2}$ at $5 \mathrm{C}$ and the proteins were eluted with the same buffer at a flow rate of $27 \mathrm{ml} / \mathrm{h}$. Each $4.0 \mathrm{ml}$ fraction was collected. Trypsin was eluted as single peak on the gel filtration and showed a single band on SDS-PAGE (Fig. 1).

For brown hakeling trypsin, the crude enzyme was chromatographed on a column of Sephacryl S-200 $(3.9 \times 64 \mathrm{~cm})$ pre-equilibrated with $10 \mathrm{mM}$ Tris-HCl buffer $(\mathrm{pH} 8.0)$ containing $1 \mathrm{mM} \mathrm{CaCl}_{2}$ at $5 \mathrm{C}$ and the proteins were eluted with the same buffer at a flow rate of $27 \mathrm{ml} / \mathrm{h}$. Each $4.0 \mathrm{ml}$ fraction was collected. The main trypsin fractions (about $60 \mathrm{ml}$ ) 
were pooled and concentrated by lyophilization to $4.0 \mathrm{ml}$. The concentrated fraction was then dialyzed against $500 \mathrm{ml}$ of $10 \mathrm{mM}$ Tris- $\mathrm{HCl}$ buffer (pH 8.0) containing $1 \mathrm{mM} \mathrm{CaCl}_{2}$ at 5 C for 6 hours. The dialyzate was applied to a DEAE-cellulose column $(2.2 \times 18 \mathrm{~cm})$ pre-equilibrated with $10 \mathrm{mM}$ Tris-HCl buffer (pH 8.0) containing $1 \mathrm{mM} \mathrm{CaCl}_{2}$ at $5 \mathrm{C}$ and the proteins were eluted with a linear gradient of $0-0.5 \mathrm{M} \mathrm{NaCl}$ in the same buffer at a flow rate of $27 \mathrm{ml} / \mathrm{h}$. Each $4.0 \mathrm{ml}$ fraction was collected. Trypsin was eluted with the non-adsorbed fraction, and was concentrated by lyophilization to $4.0 \mathrm{ml}$. Then the concentrated fraction was applied to a Sephadex G-50 column $(3.9 \times 64 \mathrm{~cm})$ pre-equilibrated with $50 \mathrm{mM}$ Tris-HCl buffer (pH 8.0) containing $1 \mathrm{mM} \mathrm{CaCl} 2$ at $5 \mathrm{C}$ and the proteins were eluted with the same buffer at a flow rate of $27 \mathrm{ml} / \mathrm{h}$. Each $4.0 \mathrm{ml}$ fraction was collected. Trypsin was eluted as single peak on the gel filtrations and showed a single band on SDS-PAGE (Fig. 1).

Trypsin activity was measured by the method of Hummel (1959) using TAME as a substrate. One unit of enzyme activity was defined as the amount of the enzyme hydrolyzing one millimole of TAME in a minute at $30 \mathrm{C}$ and at $\mathrm{pH}$ 8.0.

The $\mathrm{pH}$ dependencies of the enzyme were determined in $50 \mathrm{mM}$ buffer solutions [acetic acid-sodium acetate $(\mathrm{pH}$ 4.0-7.0), Tris- $\mathrm{HCl}(\mathrm{pH}$ 7.0-9.0), and glycine- $\mathrm{NaOH}(\mathrm{pH}$ 9.0-11.0)] at $30 \mathrm{C}$. The temperature dependencies of the enzyme were determined at $\mathrm{pH} 8.0$ and at various temperatures. The effects of temperature and $\mathrm{pH}$ on the stability of the enzyme were found by incubating the enzyme at $\mathrm{pH} 8.0$ for $15 \mathrm{~min}$ at a range of 20-70 C and by incubating the enzyme at $30 \mathrm{C}$ for $30 \mathrm{~min}$ at a range of $\mathrm{pH} 4.0-11.0$, respectively. The effect of $\mathrm{CaCl}_{2}$ on the activity of the enzyme was found by incubating the enzyme at $30 \mathrm{C}$ and at $\mathrm{pH} 8.0$ in the presence of $10 \mathrm{mM}$ EDTA or $10 \mathrm{mM} \mathrm{CaCl}_{2}$.

The effect of inhibitors on trypsin was determined according to the method of Klomklao et al. (2004) by incubating trypsin with an equal volume of the inhibitor solutions, i.e., E-64, N-ethylmaleimide, iodoacetic acid, soybean trypsin inhibitor, TLCK, TPCK, 
pepstatin A and EDTA to obtain the final concentrations specified in Table 2. After incubation the mixture at $25 \mathrm{C}$ for $15 \mathrm{~min}$, the remaining activity was measured and expressed as percent inhibition.

Sodium dodecyl sulfate-polyacrylamide gel electrophoresis (SDS-PAGE) was carried out using a $0.1 \%$ SDS-12.5 \% polyacrylamide slab-gel by the method of Laemmli (1970). The gel was stained with $0.1 \%$ Coomassie Brilliant Blue R-250 in $50 \%$ methanol-7 \% acetic acid and the background of the gel was destained with $7 \%$ acetic acid.

To analyze the N-terminal sequence the purified enzyme was electroblotted to polyvinylidenedifluoride (PVDF) membrane (Mini ProBlott Membranes, Applied Biosystems, CA, USA) after SDS-PAGE. The amino acid sequence of the enzyme was analyzed by using a protein sequencer, Procise 492 (Perkin Elmer, Foster City, CA, USA).

The protein concentration was determined by the method of Lowry et al. (1951) using bovine serum albumin as a standard.

\section{RESULTS AND DISCUSSION}

In this study, two trypsins were isolated and purified from the pyloric ceca of yellow tail and brown hakeling. The purification steps of both trypsins are summarized in Table 1, and they resulted in 63-fold and 106-fold purification, respectively, for the yellow tail and brown hakeling samples. Sephadex G-50 column chromatography was highly effective in separating trypsin from other proteins. Kishimura et al. (2005c) found that the use of Sephacryl S-200 and Sephadex G-50 for purification of trypsin from spotted mackerel (Scomber australasicus) led to an increase in trypsin activity by 20-fold. Klomklao et al. (2005) also purified the trypsins from skipjack tuna spleen by using Sephacryl S-200 and 
Sephadex G-50 an increase in purity by 40.6-fold.

The molecular weights of both yellow tail and brown hakeling trypsins were estimated as approximately $24 \mathrm{kDa}$ using SDS-PAGE (Fig. 1). Trypsin isolated from various fish species have been shown to have molecular weights of 23.5-28 kDa (Hjelmeland and Raa 1982; Yoshinaka et al. 1983; Simpson and Haard 1984; Martinez et al. 1988; Asgeirsson et al. 1989; Kristjansson 1991; Castillo-Yanez et al. 2005; Kishimura et al. 2005a; Kishimura et al. 2005b; Kishimura et al. 2005c,). Values obtained are within the accepted range of molecular weights for trypsins from $20 \mathrm{kDa}$ to $28 \mathrm{kDa}$ (Kiel 1971).

Both enzymes hydrolyzed TAME effectively at alkaline $\mathrm{pH}$ with an optimum activity at about pH 8.0 (Fig. 2a) similar to those of porcine pancreatic trypsin (Fig. 2b). Similar results have also been reported for trypsin from the hepatopancreas of crawfish which has an optimum $\mathrm{pH}$ in the range of 8.0-8.5 (Jeong et al. 2000) and for trypsin derived from cunner which has an optimum pH of 8.5 (Simpson and Haard 1985). Figure 3a shows the temperature dependencies of the yellow tail and brown hakeling trypsins. The optimum temperatures of the yellow tail and brown hakeling trypsins for the hydrolysis of TAME were $60 \mathrm{C}$ and $50 \mathrm{C}$, respectively, which were lower than that of porcine pancreatic trypsin (60-70 C; Fig. 3b). The temperature optimum of yellow tail trypsin observed $60 \mathrm{C}$, is similar to those of rainbow trout trypsin (Kristjansson 1991), Japanese anchovy trypsin (Kishimura et al. 2005a), true sardine trypsin (Kishimura et al. 2005b). On the other hand, the optimum temperature of the brown hakeling trypsin for the hydrolysis of TAME (50 C ) is similar to those of Atlantic cod trypsin (Asgeirsson et al. 1989), Monterey sardine trypsin (Castillo-Yanez et al. 2005) and arabesque greenling trypsin (Kishimura et al. 2005b).

The effects of $\mathrm{pH}$ on the stability of trypsins from the pyloric ceca of yellow tail and brown hakeling are shown in Fig. 4a. Yellow tail trypsin was stable over a broad pH range (pHs 6.0-11.0), whereas brown hakeling trypsin was stable from $\mathrm{pH} 5.0$ to $\mathrm{pH} 9.0$ after 30 
min incubation. The trypsin activity of both enzymes was rapidly lost at $\mathrm{pH}$ 4.0-5.0. On the other hand, trypsin from porcine pancreas was not inactivated at $\mathrm{pH}$ 4.0-5.0(Fig. 4b). The sharp decrease in the fish trypsin activities at low $\mathrm{pH}$ may be attributed to the irreversible denaturation of the enzymes (Klomklao et al. 2005). A similar inactivation at acidic $\mathrm{pH}$ also occurred with trypsins from other fish species (Martinez et al. 1988; Asgeirsson et al. 1989; Kristjansson 1991; Kishimura et al. 2005a, b, c). Figure 5a shows the temperature stabilities of the yellow tail and brown hakeling trypsins. The yellow tail trypsin was stable below 40 C, but its activity quickly fell above $50 \mathrm{C}$. The temperature stability of the yellow tail trypsin was similar to that of Monterey sardine trypsin (Castillo-Yanez et al. 2005) and Japanese sardine trypsin (Kishimura et al. 2005b). Whereas the brown hakeling trypsin was stable below $30 \mathrm{C}$, and its activity quickly fell above $40 \mathrm{C}$. The results indicated that the brown hakeling trypsin was more heat labile than the yellow tail trypsin, other fish trypsins (Martinez et al. 1988; Kristjansson 1991) and porcine pancreatic trypsin (Fig. 5b).

The effects of $\mathrm{CaCl}_{2}$ on the yellow tail and brown hakeling trypsins were investigated in the presence of $10 \mathrm{mM}$ EDTA or $10 \mathrm{mM} \mathrm{CaCl}_{2}$. As shown in Figs. 6a and 6b, both enzymes were stabilized by calcium ion similar to porcine pancreatic trypsin. Two calcium-binding sites are in bovine trypsinogen (Kossiakoff et al. 1977). The primary site, with a higher affinity for calcium ions, is common in trypsinogen and trypsin, and the secondary site is only in the zymogen. Occupancy of the primary calcium-binding site stabilizes the protein toward thermal denaturation or autolysis. From the results, the yellow tail and brown hakeling trypsins were stabilized by calcium ion from thermal denaturation. These findings suggest that the yellow tail and brown hakeling trypsins possess the primary calcium binding site like mammalian pancreatic trypsin and other fish trypsins (Male et al. 1995; Genicot et al. 1996; Kishimura et al. 2005a, b).

Protease inhibitors are very important tools to characterize active sites and to 
understand enzymatic mechanisms (Klomklao et al. 2004). Table 2 presents the effects of eight different inhibitors on the trypsins from the pyloric ceca of yellow tail and brown hakeling. Both enzymes were strongly inhibited by soybean trypsin inhibitor and TLCK, which are widely used to identify trypsins, whereas, TPCK (a synthetic chymotrypsin inhibitor), E-64, N-ethylmaleimide, iodoacetic acid (cysteine protease inhibitors) and pepstatin A (an aspartic protease inhibitor) had no inhibitory effect on both trypsins. However, a metallo protease inhibitor (EDTA) showed partially inhibition. The responses of both enzymes to these eight inhibitors suggest that these enzymes may be classified as trypsins, which possibly require metal ions for activity. Similar results were obtained for other fish trypsins (Hjelmeland and Raa 1982; Simpson and Haard 1984; Kristjansson 1991; Klomklao et al. 2004; Kishimura et al. 2005c).

The N-terminal amino acid sequences of the purified trypsins from yellow tail and brown hakeling were determined for twenty amino acid residues as, IVGGYECKPYSQPHQVSLNS and IVGGYECPKHSQPHQVSLNS, respectively. It was indicated that the N-termini of both trypsins were unblocked. The N-terminal amino acid sequences of the yellow tail and brown hakeling trypsins were aligned with the sequences of other animal trypsins (Fig. 7). Being similar to other fish trypsins, the yellow tail and brown hakeling trypsins had a charged Glu residue at position 6, whereas Thr is most common in mammalian pancreatic trypsins (Fig. 7). In this study, the Cys residue was conserved in the yellow tail and brown hakeling trypsins (Fig. 7). The results indicate that the yellow tail and brown hakeling trypsins may also have a disulfide bond to the corresponding residues (between Cys-7 and Cys-142) of bovine pancreatic trypsin. 


\section{CONCLUSION}

Yellow tail trypsin showed similar characteristics as porcine pancreatic trypsin except for instability below pH 5.0. On the other hand, the brown hakeling trypsin showed lower optimum temperature than that of porcine pancreatic trypsin and both was less stable than porcine pancreatic trypsin below pH 5.0 and above $40 \mathrm{C}$.

\section{ACKNOWLEDGMENT}

The authors wish to thank Mr. T. Hirose, the Center for Instrumental Analysis, Hokkaido University, for amino acid sequence analysis. 


\section{REFERENCES}

ASGEIRSSON, B., FOX, J.W. and BJARNASON, J.B. 1989. Purification and characterization of trypsin from the poikilotherm Gadus morhua. Eur. J. Biochem. 180, 85-94.

CASTILLO-YANEZ, F.J., PACHECO-AGUILAR, R.,GARCIA-CARRENO, F.L. and TORO, M.A.N. 2005. Isolation and characterization of trypsin from pyloric caeca of Monterey sardine Sardinops sagax caerulea. Comp. Biochem. Physiol. 140B, 9198.

EMI, M., NAKAMURA, Y., OGAWA, M., YAMAMOTO, T., NISHIDE, T., MORI, T. and MATSUBARA, K. 1986. Cloning, characterization and nucleotide sequences of two cDNAs encoding human pancreatic trypsinogens. Gene 41, 305-310.

GENICOT, S., RENTIER-DELRUE, F., EDWARDS, D., VANBEEUMEN, J. and GERDAY, C. 1996. Trypsin and trypsinogen from Antarctic fish: molecular basis of cold adaptation. Biochim. Biophys. Acta 1298, 45-57.

GUDMUNDSDOTTIR, A., GUDMUNDSDOTTIR, E., OSKARSSON, S., BJARNASON, J.B., EAKIN, A.K. and CRAIK, C.S. 1993. Isolation and characterization of cDNAs from Atlantic cod encoding two different forms of trypsinogen. Eur. J. Biochem. 217, 1091-1097.

HAARD, N.F. 1992. A review of proteolytic enzymes from marine organisms and their application in food industry. J. Aquatic Food Prod. Technol. 1, 17-35.

HERMODSON, M.A., ERICSSON, L.H., NEURATH, H. and WALSH, K.A. 1973.

Determination of the amino acid sequence of porcine trypsin by sequenator analysis. Biochemistry 12, 3146-3153.

HJELMELAND, K. and RAA, J. 1982. Characteristics of two trypsin type isozymes isolated 
from the Arctic fish capelin (Mallotus villosus). Comp. Biochem. Physiol. 71B, 557562.

HUMMEL, B.C.W. 1959. A modified spectrophotometric determination of chymotrypsin, trypsin, and thrombin. Can. J. Biochem. Physiol. 37, 1393-1399.

JEONG, Y., WEI, C-I, PRESTON, J.F. and MARSHALL, M.R. 2000. Purification and characterization of proteases from hepatopancreas of crawfish (Procambarus clarkii). J. Food Biochem. 24, 311-332.

KEIL, B. 1971. Trypsin. In The enzymes, (P.D. Boyer, ed), pp249-275, New York.

KISHIMURA, H. and HAYASHI, K. 2002. Isolation and characteristics of trypsin from pyloric ceca of the starfish Asterina pectinifera. Comp. Biochem. Physiol. 132B, 485-490.

KISHIMURA, H., HAYASHI, K., MIYASHITA, Y. and NONAMI, Y. 2005a. Characteristics of two trypsin isozymes from the viscera of Japanese anchovy (Engraulis japonica). J. Food Biochem. ( in press).

KISHIMURA, H., HAYASHI, K., MIYASHITA, Y. and NONAMI, Y. 2005b. Characteristics of trypsins from the viscera of true sardine (Sardinops melanostictus) and the pyloric ceca of arabesque greenling (Pleuroprammus azonus). Food Chem. (in press).

KISHIMURA, H., KLOMKLAO, S., BENJAKUL, S. and ANDO, S. 2005c. Enzymatic characteristics of trypsin from the pyloric ceca of spotted mackerel (Scomber australasicus). J. Food Biochem. (in press).

KLOMKLAO, S., BENJAKUL, S. and VISESSANGUAN, W. 2004. Comparative studies on proteolytic activity of spleen extracts from three tuna species commonly used in Thailand. J. Food Biochem. 28, 355-372.

KLOMKLAO, S., BENJAKUL, S., VISESSANGUAN, W., KISHIMURA, H. and 
SIMPSON, B. K. 2005. Purification and characterization of trypsins from skipjack tuna (Katsuwonus pelamis) spleen. Food Chem. (in review).

KOSSIAKOFF, A.A., CHAMBERS, J.L., KAY, L.M. and STROUD, R.M. 1977. Structure of bovine trypsinogen at 1.9A resolution. Biochemistry 16, 654-664.

KRISTJANSSON, M.M. 1991. Purification and characterization of trypsin from the pyloric caeca of rainbow trout (Oncorhynchus mykiss). J. Agr. Food Chem. 39, 1738-1742.

LAEMMLI, U.K. 1970. Cleavage of structural proteins during the assembly of the head of bacteriophage T4. Nature 227, 680-685.

LOWRY, O.H., ROSEBROUGH, N.J., FARR, A.L. and RANDALL, R.J. 1951. Protein measurement with the Folin phenol reagent. J. Biol. Chem. 193, 265-273.

MALE, R., LORENS, L.B., SMALAS, A.O. and TORRISSEN, K.R. 1995. Molecular cloning and characterization of anionic and cationic variants of trypsin from Atlantic salmon. Eur. J. Biochem. 232, 677-685.

MARTINEZ, A., OLSEN, R.L. and SERRA, J.L. 1988. Purification and characterization of two trypsin-like enzymes from the digestive tract of anchovy Engraulis encrasicholus. Comp. Biochem. Physiol. 91B, 677-684.

RYPNIEWSKI, W., PERRAKIS, A., VORGIAS, C.E. and WILSON, K.S. 1994. Evolutionary divergence and conservation of trypsin. Protein Engineering 7, 57-64.

SIMPSON, B.K. and HAARD N.F. 1984. Trypsin from Greenland cod, Gadus ogac. Isolation and comparative properties. Comp. Biochem. Physiol. 79B, 613-622.

SIMPSON, B.K. and HAARD N.F. 1985. Characterization of the trypsin fraction from cunner (Tautogolabrus adspersus). Comp. Biochem. Physiol. 80B, 475-480.

SIMPSON, B.K. and HAARD N.F. 1987. Cold-adapted enzymes from fish. In Food Biotechnology, (D. Knorr, ed.), pp. 495-528, New York.

WALSCH, K.A. 1970. Trypsinogens and trypsins of various species. Methods Enzymol. 
19, 41-63.

YOSHINAKA, R., SUZUKI, T., SATO, M. and IKEDA, S. 1983. Purification and some properties of anionic trypsin from the catfish pancreas. Bull. Jap. Soc. Sci. Fish. 49, 207-212. 
(captions to figures)

FIG. 1. ELECTROPHORESIS OF PURIFIED TRYPSINS FROM YELLOW TAIL (S. QUINQUERADIATA) AND BROWN HAKELING (P. JAPONICUS).

Electrophoresis was performed using a $0.1 \%$ SDS-12.5 \% polyacrylamide slab-gel. Lane 1 contains trypsin from yellow tail (S. quinqueradiata). Lane 2 contains trypsin from brown hakeling (P. japonicus). Lane 3 contains protein standards; egg albumin (molecular weight, 45,000 Da), bovine pancreatic trypsinogen (24,000 Da), bovine milk $\beta$-lactoglobulin (18,400 Da), and egg-white lysozyme (14,300 Da).

FIG. 2. EFFECTS OF pH ON THE ACTIVITY OF TRYPSINS FROM YELLOW TAIL (S. QUINQUERADIATA) AND BROWN HAKELING (P. JAPONICUS).

The activities were determined in $50 \mathrm{mM}$ buffer solutions [acetic acid-sodium acetate $(\mathrm{pH}$ 4.0-7.0), Tris- $\mathrm{HCl}(\mathrm{pH} 7.0-9.0)$, and glycine- $\mathrm{NaOH}(\mathrm{pH} 9.0-11.0)]$ at $30 \mathrm{C}$. a: trypsin from yellow tail (S. quinqueradiata) (closed circle); trypsin from brown hakeling (P. japonicus) (closed triangle), b: porcine pancreatic trypsin.

FIG. 3. EFFECTS OF TEMPERATURE ON THE ACTIVITY OF TRYPSINS FROM YELLOW TAIL (S. QUINQUERADIATA) AND BROWN HAKELING ( $P$. JAPONICUS).

The activities were determined at $\mathrm{pH} 8.0$ and at various temperatures. a: trypsin from yellow tail (Seriola quinqueradiata) (closed circle); trypsin from brown hakeling (P. japonicus) (closed triangle) (closed triangle), b: porcine pancreatic trypsin. 
FIG. 4. $\quad$ pH STABILITY OF TRYPSINS FROM YELLOW TAIL (S. QUINQUERADIATA) AND BROWN HAKELING (P. JAPONICUS).

The enzymes were kept at $30 \mathrm{C}$ for $30 \mathrm{~min}$ and $\mathrm{pH} 4.0-11.0$, and then the remaining activities at $30 \mathrm{C}$ and $\mathrm{pH} 8.0$ were determined. a: trypsin from yellow tail (S. quinqueradiata) (closed circle); trypsin from brown hakeling ( $P$. japonicus) (closed triangle), b: porcine pancreatic trypsin.

FIG. 5. THERMOSTABILITY OF TRYPSINS FROM YELLOW TAIL (S. QUINQUERADIATA) AND BROWN HAKELING (P. JAPONICUS).

The enzymes were kept at 20-70 C for $15 \mathrm{~min}$ and $\mathrm{pH}$ 8.0, and then the remaining activities at $30 \mathrm{C}$ and $\mathrm{pH} 8.0$ were determined. a: trypsin from yellow tail (S. quinqueradiata) (closed circle); trypsin from brown hakeling (P. japonicus) (closed triangle), b: porcine pancreatic trypsin.

FIG. 6. EFFECT OF CALCIUM ION ON THE STABILITY OF TRYPSINS FROM YELLOW TAIL (S. QUINQUERADIATA) AND BROWN HAKELING ( $P$. JAPONICUS).

The enzymes were kept at $30 \mathrm{C}$ and $\mathrm{pH} 8.0$ for $0-8 \mathrm{~h}$ in the presence of $10 \mathrm{mM} \mathrm{CaCl}_{2}$ (closed symbol) or $10 \mathrm{mM}$ EDTA (open symbol), and then the remaining activities at $30 \mathrm{C}$ and $\mathrm{pH} 8.0$ were determined. a: trypsin from yellow tail (S. quinqueradiata) (circle); trypsin from brown hakeling (P. japonicus) (square), b: porcine pancreatic trypsin. 
FIG. 7. COMPARISON OF THE N-TERMINAL AMINO ACID SEQUENCES OF TRYPSINS FROM YELLOW TAIL (S. QUINQUERADIATA) AND BROWN HAKELING (P. JAPONICUS) WITH THOSE OF OTHER VERTEBRATES.

True sardine (Kishimura et al. 2005b); Arabesque greenling (Kishimura et al. 2005b); Japanese anchovy (Kishimura et al. 2005a); Antarctic fish (Genicot et al. 1996); Cod (Gudmundsdottir et al. 1993); Salmon (Male et al. 1995); Founder fish (GenBank accession number AB029750); Porcine (Hermodson et al. 1973); Bovine (Walsch 1970); Human (Emi et al. 1986). 
Fig. 1

45. $0 \mathrm{kDa}$

$-\leftarrow 24.0 \mathrm{kDa}$
$-\longleftarrow 18.4 \mathrm{kDa}$
$\leftarrow 14.3 \mathrm{kDa}$

$\begin{array}{lll}1 & 2 & 3\end{array}$ 
Fig. 2

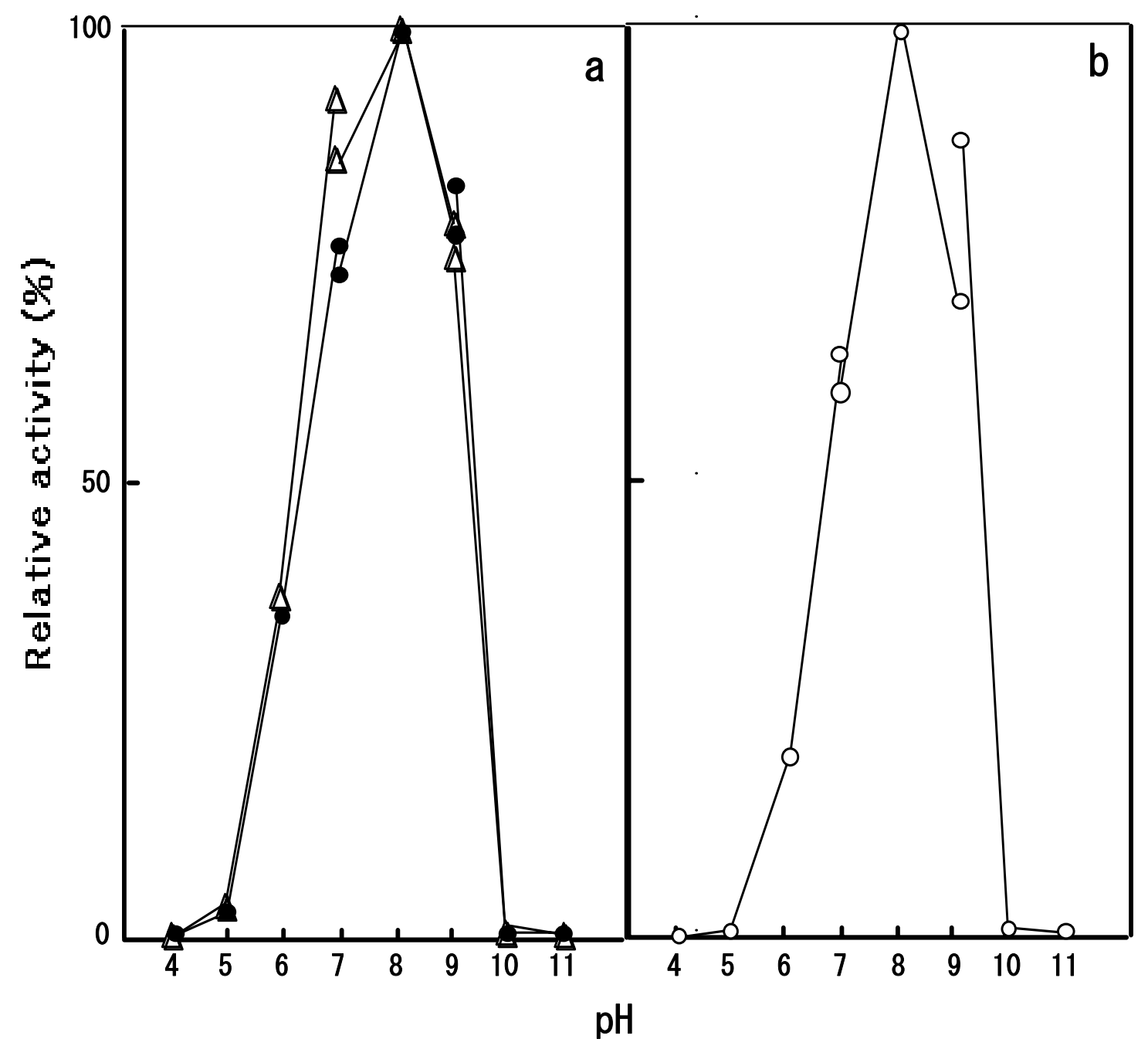


Fig. 3

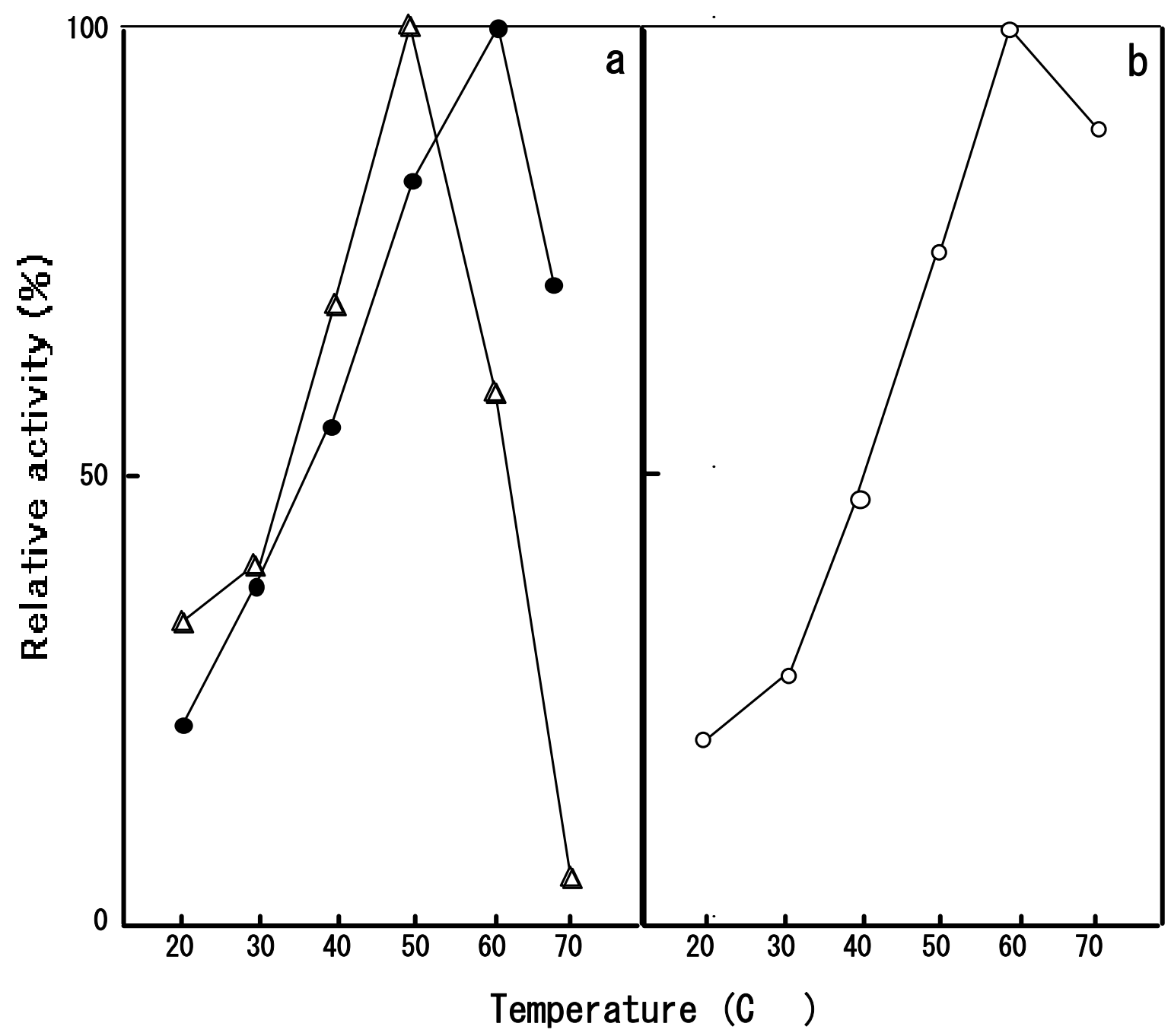


Fig. 4

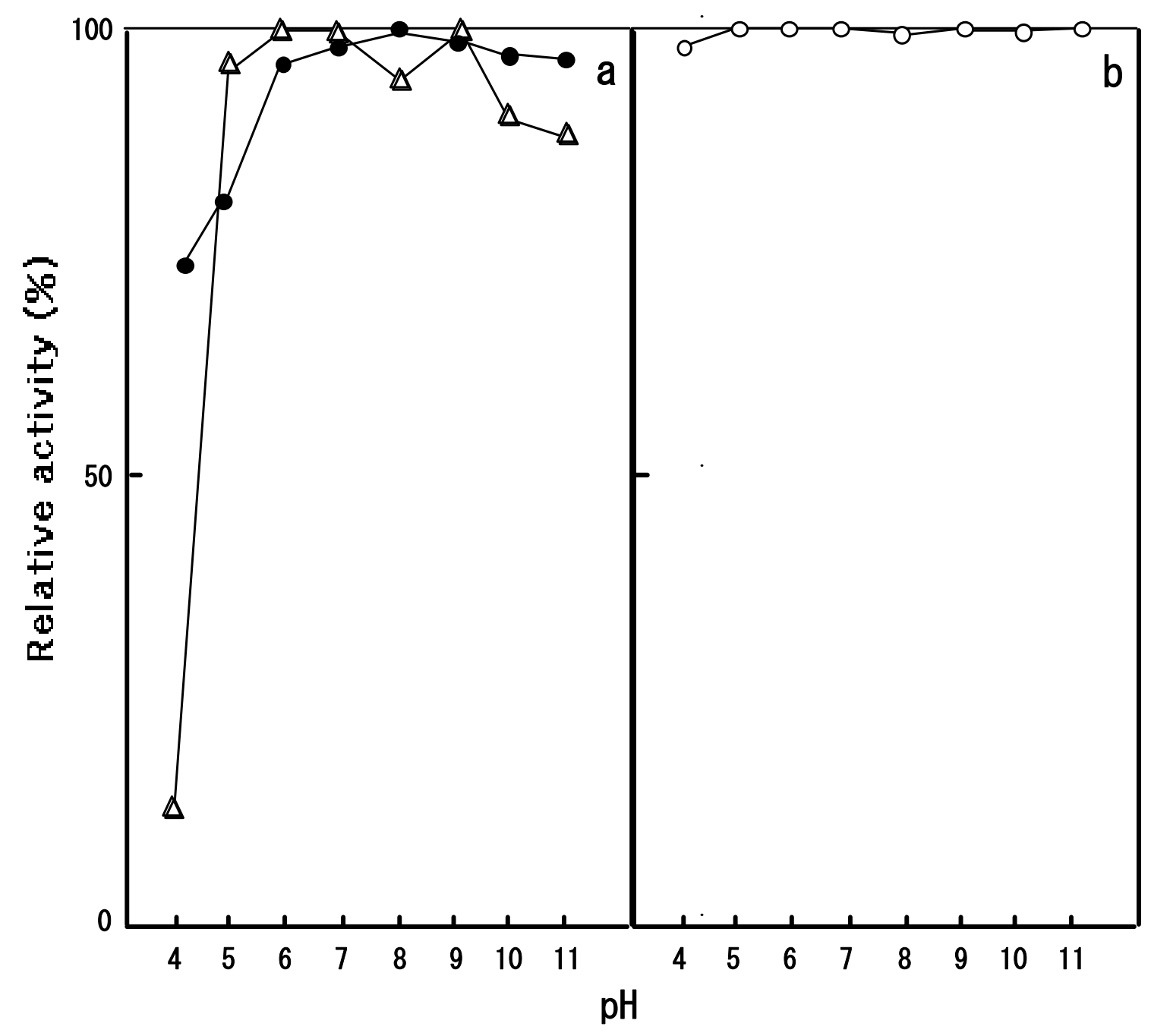


Fig. 5

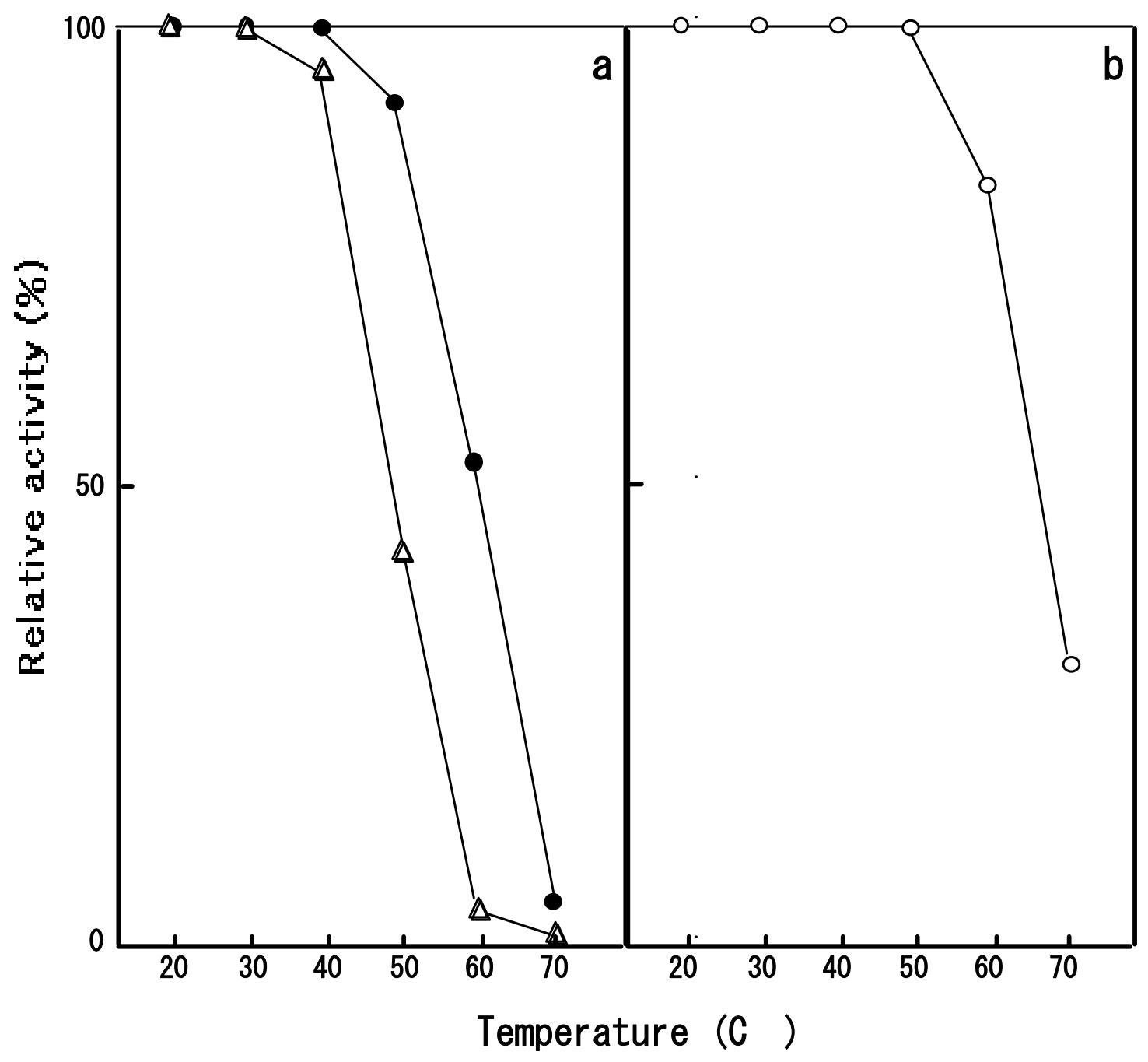


Fig. 6

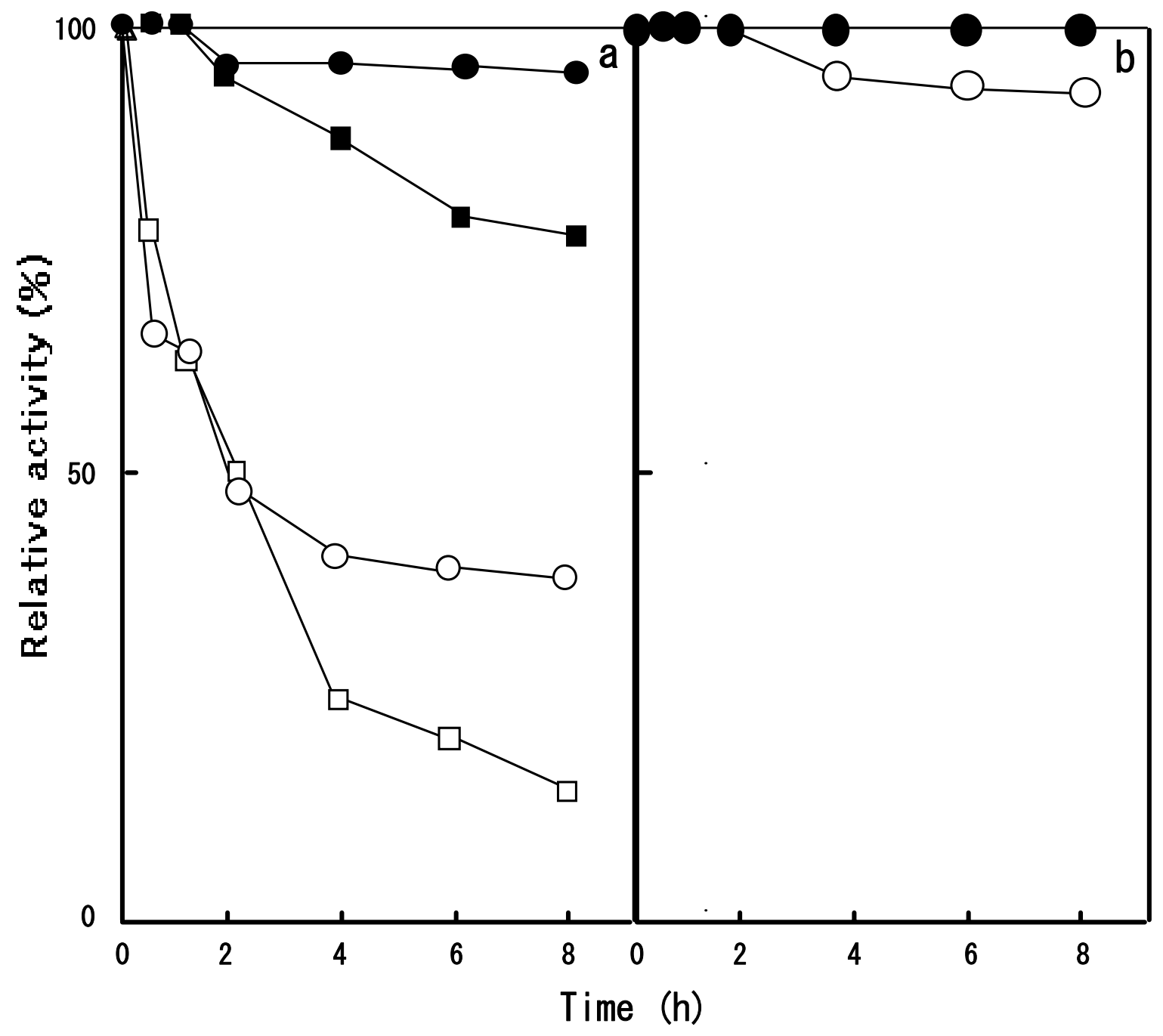


Yellow tail

Brown hakeling

True sardine

Arabesuque greenling Japanese a nchovy (TR-I) Japanese anchovy (TR-II) Antarctic Fish

Cod

Salmon

Flounder Fish

Porcine

Bovine

Human
$1 \quad 10 \quad 20$

IVGGYECKPYSQPHQVSLNS IVGGYECTPHSQAHQVSLNS

IVGGYECKAYSQPWQVSLNS IVGGYECTPHTQAHQVSLDS IVGGYECQAHSQPHTVSLNS IVGGYECQPYSQPHQVSLDS IVGGKECSPYSQPHQVSLNS IVGGYECTKHSQAHQVSLNS IVGGYECKAYSQTHQVSLNS IVGGYECTPYSQPHQVSLNS IVGGYTCAANSVPYQVSLNS IVGGYTCGANTVPYQVSLNS IVGGYNCEENSVPYQVSLNS 
TABLE 1.

PURIFICATION OF TRYPSINS FROM YELLOW TEIQUNQUERADIA)TAND BROWN HAKELING ( P. JAPONICUS

\begin{tabular}{|c|c|c|c|c|c|}
\hline Purification stages & $\begin{array}{l}\text { Protein } \\
\text { (mg) }\end{array}$ & $\begin{array}{l}\text { Total } \\
\text { activity } \\
\text { (U) }\end{array}$ & $\begin{array}{l}\text { Specific } \\
\text { activity } \\
(\mathrm{U} / \mathrm{mg})\end{array}$ & $\begin{array}{l}\text { Purity } \\
\text { (fold) }\end{array}$ & $\begin{array}{l}\text { Yield } \\
(\%)\end{array}$ \\
\hline \multicolumn{6}{|l|}{ yellow tail } \\
\hline Crude enzyme & 3,810 & 346 & 0.18 & 1 & 100 \\
\hline Sephacryl S-200 & 1,138 & 283 & 1.0 & 6 & 82 \\
\hline Sephadex G-50 & 34 & 190 & 17.2 & 96 & 55 \\
\hline \multicolumn{6}{|l|}{ brown hakeling } \\
\hline Crude enzyme & 6,440 & 773 & 0.12 & 1 & 100 \\
\hline Sephacryl S-200 & 638 & 510 & 0.8 & 7 & 66 \\
\hline DEAE-Cellulose & 33 & 310 & 9.4 & & 40 \\
\hline Sephadex G-50 & 6 & 76 & 12.7 & 106 & 10 \\
\hline
\end{tabular}


TABLE 2.

EFFECTS OF VARIOUS INHIBITORS ON THE ACTIVITY OF TRYPSINS FROM YELLOW TAIL ( $S$. QUINQUERADIA TAAND BROWN HAKELINGR JAPONICUS

\begin{tabular}{lccc}
\hline Inhibitors & Concentration & \multicolumn{2}{c}{ \% Inhibition } \\
\cline { 3 - 4 } & & yellow tail & brown hakeling \\
\hline Control & $0.1 \mathrm{mM}$ & 0 & 0 \\
E-64 & $1 \mathrm{mM}$ & 0 & 0 \\
N-ethylmaleimide & 1 & $\mathrm{mM}$ & 0 \\
Iodoacetic acid & $\mathrm{mg} / \mathrm{ml}$ & 0 & 93 \\
Soybean trypsin inhibitor & 1 & 96 & 86 \\
TLCK & $5 \mathrm{mM}$ & 80 & 6 \\
TPCK & $5 \mathrm{mM}$ & 9 & 0 \\
Pepstatin A & $0.01 \mathrm{mM}$ & 0 & 21 \\
EDTA & $2 \mathrm{mM}$ & 29 & \\
\hline
\end{tabular}

